neath and overlapping. Abdonen depressed, somewhat bigibbous in front. Characterized more particularly by the form of the epigynum. (cf. Plate X, fig. 6.).

Length, $5 \mathrm{~mm}$.

Several females.

Tibellus duttonii Hentz.

One female apparently this species.

Olios fasciculatus Simon.

Two females.

Pardosa sternalis Thorell.

Several females and males. This is one of he commonest spiders found in the intermountain region.

Lycosa apicata Banks.

One male. The species has not previously been taken in the region.

One female.

Oxyopes salticus Hentz.

Three females.

Phidippus workmanii Peckham.

Phidippus formosus Peckham.

One female.

Salticus albocinctus Peckham.

A male and female. Previonsly known from Arizona and Mexico.

Eurypelma steindachneri (Ausserer).

One female.

SCORPIONIDA.

Hadrurus hirsutus (Wood).

One specimen of this large form.

Velovis mexicanus (Koch).

One specimen.

Explatition of Plate X.

Fig. I.--Physocyclus tanneri, sp. n., lateral view of body. $x$ Io. 2.-The same, epigynum, ventral view. $x$ 33. 3.-The same, ectal view of epigynum. x. 33. 4.-Physocychs globosus Tacz., epigynum, ectal view. $\mathrm{x}$ 33. 5.-Physocyclus cornutus Bks., epigynum, ectal view. $\mathrm{x}$ 33. 6.-Philodromus utus, sp. n., epigynum, ventral view. $\times 3^{8}$.

\title{
A REVISION OF THE NEARCTIC SPECIES OF THE TACHINID GENUS ERNESTIA R. D. (DIPTERA)
}

BY DR. JOHN D. TOTHILL

In Charge of Natural Control Inrestigations, Entomologieal Branch, Ottawa.

(Continued from Page 230)

Ernestia nigropalpis sp. n.

Head at vibrissae about as thick as at base of antennae; vibrissae far above the oral margin. Palpi black. Eyes hairy. Cheeks (below the eyes) white pollinose on a black ground with black hairs coming nearly up to the 
eyes and with a row of stouter hairs at the oral margin. Distance from the oral margin to base of eye equal to about one-third the eye height. Sides of face covered with silvery pollen; bare; narrowest width slightly less than the length of the second antennal segment and equal to about one-third the distance between the vibrissae. Facial ridges bristly on lowest fifth. Facial depression silvery pollinose, without any carina. Antenna in male reaching lowest three-fourths of the face, all three segments black; third segment in male almost twice as long as the second. Arista thickened on basal two-fifths; the penultimate segment no longer than broad; width of front in male at narrowest point measuring slightly less than the length of the second antennal segment, silvery pollinose becoming black at vertex; frontal vitta dull, darkbrown, at narrowest point slightly wider than either side of front. No orbital bristles in male; the frontal bristles extending to base of third antennal segment. Ocellar bristles present in male, directed forward.

Thorax subshining, black, covered with grey pollen; scutellum grey pollinose on a black ground tinged faintly reddish at apex. Three sternopleural bristles and three to four post suturals; scutellum with three marginal pairs of machrochaetae and a terminal cruciate pair. Legs black, the middle tibiae with two or more bristles on the front side near the middle, the hind tibiae without a comb-like row of bristles on the outer side. Wings hyaline; $R_{4+5}$ (third vein) with a group of three to five bristles at the base on both the upper and lower surface. Tegulae white.

Abdomen subshining; silvery pollinose on a black ground. Discal bristles present on the second, third and fourth abdominal segments; a pait of median marginal machrochaetae also present on each of these segments. The fifth tergum very narrow and rather indistinctly marked off by a suture from the sixth tergum with which it is united. Sixth abdominal segnent almost as long as the fourth and forming a conspicuous genital segment.

The black genitalia of the male are characterized by there being a short median keel situated on the basal part of the inner forceps (valvae internae), and by the fact that this keel is not concave in profile on either of its two margins.

The horseshoe-like indenture of the fifth sternite extends rather less than half way into the sternite.

Described from eleven males taken at Franconia N.H., Stickeen River, B. C. (type locality), and Savary Island, B. C., by Messrs. C. H. T. Townsend, Wickham and R. S. Sherman.

Type in the Canadian National Collection, Ottawa. 'The paratype, No. 24354, from Franconia in the U. S. N. M., Washington, D.C.

\section{Ernestia arcuata sp. n.}

Head at vibrissae about as thick as at base of antennae; vibrissae far above the oral margin. Palpi usually yellow at the tip and infuscated basally, occasionally black. Eyes hairy, cheeks (below the eyes) white pollinose on a black ground, subshining on the lower part that is covered with black hairs, a row of stouter hairs at the oral margin. Distance from the oral margin to base of eye equal to about one-third the eye height. Sides of face covered with silvery pollen; bare; narrowest width in male slightly less than the length of 
the second antennal segment and equal to about two-fifths the distance between the vibrissae. Facial ridges bristly on lowest fourth. Facial depression silvery pollinose, without any carina. Antennae in male reaching the lowest fourth of the face, all three segments black; third segment in male about one and onehalf times as long as the second. Arista thickened on basal two-fifths to onehalf, the penultimate segment scarcely longer than broad. Width of front in male at narrowest point measuring slightly less than the length of the second antennal segment; the front silvery pollinose; frontal vitta dull, dark brown, at narrowest point-in male--slightly wider than either side of front just cephalad of the ocellar triangle. No orbital bristles in male, the proclinate ocellars somewhat weak and reduced in cases to mere hairs; the single row of frontal bristles decending nearly to the base of the third antennal segment.

Thorax subshining, black, covered with gray pollen; scutellum gray pollinose on a black ground in most specimens tinged reddish, especially at the apex. Typically three sternopleural bristles but considerable variation noticeable in the type material; typically four dorsocentral bristles, but these likewise vary considerably in the type material; scutellum with three marginal pairs of machrochaetae and an apical cruciate pair. Legs black, the middle tibiae with two ot more bristles on the front side near the middle, the hind tibiae without a comb-like row of bristles on the outer side. Wings hyaline; $\mathrm{R}_{4+5}$ (third vein) with a group of two to five hairs both above and below at the junction with $R_{2+3}$. Tegulae white.

Abdomen subshining; silvery pollinose on a black ground that occasionally becomes reddish, particularly on the lateral parts of the first three segments. Discal machrochaetae present on the second, third and fourth abdominal segments; median marginals present on the same segments. The hind margin of the third tergum strongly arcuate. The fifth tergum distinctly marked off by a suture from the sixth or first genital segment and laterally being a third as long as the lateral part of the fourth abdominal segment. The sixth and seventh abdominal segments forming somewhat distended genital segments.

Male genitalia black. The basal part of the outer forceps is expanded into a broad, leaf-like portion. The basal part of the inner forceps is equipped with a short median, keel-like projection, the basal edge of which is concave in profile.

The horseshoe-like indenture extends rather more than half way to the base of the fifth sternite.

Described from ten males taken at Great Falls, Va., (type locality), Mount Vernon, Va., Cabin John Bridge, Maryland, Bladensburg, Md, Plummers Island, Md., Hartford, Conn., Malden, Mass.. and North Saugus, Mass. Material collected in April and May.

Type No. 24355 in the U. S. N. M.. Washington, D.C. A paratype in the National Collection at Ottawa.

\section{Ernestia incisa sp. n.}

Description of male. Head at vibrissae nearly as thick as at base of antennae, vibrissae far above the oral margin. Palpi in the single type speci- 
men black. Eyes hairy. Cheeks (below the eyes) white pollinose on a black ground, subshining on the lower part that is covered with black hairs, a row of stouter hairs or bristles at the oral margin. Distance from the oral margin to the base of eye equal to about one-third the eye height. Sides of face covered with silvery pollen; bare; narrowest width equal to the length of the second antennal segment. Facial ridges bristly on the lowest fourth. Facial depression silvery pollinose, without any carina. Antennae reaching the lowest fourth of the face, all three segments black; third segment about one and one-half times as long as the second. Arista thickened on basal two-fifths, the penultimate section scarcely longer than broad. Width of front at narrowest point measuring slightly greater than the length of the second antennal segment, the front silvery pollinose; frontal vitta dull, dark-brown, at narrowest point slightly wider than either side of front just cephalad of the ocellar triangle. No orbital bristles, the ocellars proclinate; the single row of frontal bristles extending nearly to the base of the third antennal segment.

Thorax subshining, black, covered with gray pollen; scutellum gray pollinose on a black ground that is very slightly reddened at the apex. Three sternopleural bristles and four pairs of dorso-centrals. Scutellum witn three pairs of marginal macrochaetae and an apical cruciate pair. Legs black, the middle tibiae with two or more bristles on the front side near the middle; the hind tibiae without a comb-like row of bristles on the outer side. Wings hyaline: $R_{i-5}$ (third vein) with a group of five to ten hairs both above and belor at the junction with $\mathrm{R}_{--3 .}$. Tegulae white.

Abdomen subshining; silvery pollinose on a black ground. Discal and niedian marginal macrochaetae on segments two, three and four. The hind margin of the third tergum sightly arcuate. The fifth tergum which is pollinose, clearly marked off from the sixth which is shining; the fifth tergum is at its greatest length about one-fifth the length of the lateral part of the fourth. The sixth and seventh abdominal segments form the somewhat distended genital segments.

Male genitalia black. The basal part of the outer forceps is expanded into a broad, leaf-like portion. The basal part of the inner forceps is equipped with a short median, keel-like projection, the basal edge of which is very slightly concave in profile.

The horseshoe-like indenture extends a little less than half way to the base of the fifth sternite. The outer edges of the prongs are deeply incised, thus affording a character that serves to separate the species from any other North American species.

Described from a single male taken at Carlisle Junction, Pa., by W. R. Walton.

Type No. $2435^{6}$ in the U. S. National Museum, Washington, D. C.

\section{Ernestia aldrichi Town.}

Head at vibrissae about as thick as at base of antennae; vibrrssae well above the oral margin. Palpi dusky yellow to almost black. Eyes hairy. Cheeks (below the eyes) white pollinose on a black ground, subshining on 
the lower hairy part, a row of bristles at the oral margin. Distance from the oral margin to base of eye equal to about one-third the eye height; sides of face covered with silvery pollen; bare; narrowest width not quite equal to the length of the second antennal segment. Facial ridges bristly on the lowest fourth. Facial depression silvery pollinose, without any carina. Antennae reaching the lowest fourth of face, all three segments black; third segment about one and one-fourth times as long as the second. Arista thickened on basal two-fifths to one-half, the penultimate segment slightly longer than broad. Width of front in both sexes about twice the length of the second antennal segment; the front silvery pollinose; frontal vitta dull, dark-brown, at narrowest point one and one-half to twice as wide as either side of front just cephalad of the ocellar triangle. One pair of orbital bristles in the male, two pairs in the female. Ocellar bristles present in both sexes and proclinate, the single row of frontal bristles descending almost to the base of the third antennal segment.

Thorax subshining, black, covered with gray pollen; scutellum gray pollinose on a black ground. Typically three sternopleural and four dorsocentral macrochaetae but both sets are quite variable; scutellum usually with three pairs of marginal and one pair of cruciate apical bristles. Legs black, the middle tibiae with two or more bristles on the front side near the middle, the hind tibiae without a comb-like row of bristles on outer side. Wings hyaline. $R_{4+5}$ (third vein) with a group of two to five hairs both above and below at the junction with $R_{2+3}$. Bend of $M_{1+2}$ with a very short appendage in a few of the males, otherwise destitute of an appendage. Tegulae white.

Abdomen subshining; silvery pollinose on a black ground. Discal and marginal macrochaetae present on the second, third and fourth abdominal segments. The hind margin of the third tergite somewhat arcuate in the male. The fifth tergum in the male marked off from the shining sixth by a suture, longer laterally than medially, laterally about one-fifth the length of the lateral part of the fourth tergum. 'The sixth and seventh abdominal segments in the male forming the somewhat prominent genital segments.

Genital segments of the male black. The basal part of the outer forceps covered by a leaflike expansion. The basal part of the inner forceps with a long median, keel-like projection.

The indenture in the last sternite of the male extending half the distance toward the base of the sternite.

Redescribed from the type material consisting of three males and four females, from Brookings, S. D., in the U. S. N. M., Washington, D. C. One paratype transferred by courtesy of the collector, Dr. J. M. Aldrich, to the Canadian National Collection, Ottawa.

\section{Ernestia longicarina sp. n.}

Description of male. Head at vibrissae almost as thick as at base of antennae; vibrissae far above the oral margin. Palpi yellow. Eyes hairy. Cheeks (below the eyes) pale golden pollinose on a black ground, subshining on the lower hairy part, a row of bristles at the oral margin. Distance from oral margin to base of eye equal to about one-third the eye height. Sides of face pale golden pollinose; bare; narrowest width slightly less than the length of the second antennal segment. Facial ridges bristly on the lowest fourth. Facial 
depression pale golden pollinose without any carina. Antennae reaching lowest fourth of face, all three segments black; the third segment about one and onefourth times as long as the second. Arista thickened on basal half, the penultimate segment scarcely longer than broad. Width of front at narrowest point equal to about three-fourths the length of the second antennal segment; the front silvery pollinose; frontal vitta reddish brown, the narrowest width equal to about one-half the width of front at vertex. No orbital bristles, the proclinate ocellar bristles fairly well developed; the single row of frontal bristles descending to about the middle of the second antennal segment.

Thorax subshining, black, covered with gray pollen, scutellum gray pollinose on a black ground and showing no red coloration even at the extreme tip. Typically three sternopleural bristles and three pairs of dorsocentrals; scutellum with three strong pairs of marginal macrochaetae, with an apical cruciate weaker pair and without any discals. Legs black, the middle tibiae with two or more bristles on the front side near the middle, the hind tibiae without a comb-like row of bristles on the outer sicle. Wings hyaline; $\mathrm{R}_{4+5}$ (third vein) with a group of two to five hairs both above and below at the junction of $\mathrm{R}_{2+3}$; the bend of $\mathrm{M}_{1+2}$ destitute of an appendage. Tegulae white.

Abdomen subshining; very lightly silvery pollinose on a black ground. Discal and marginal macrochaetae present on the second, third and fourth abdominal segments. The hind margin of the third tergum very strongly arcuate; the fifth tergum readily marked off from the sixth at the lateral part but medially indistinguishable from it. The lateral width of the fifth tergum equal to about one-third the lateral width of the fourth abdominal segment; the sixth and seventh abdominal segments forming the somewhat distended genital seg11nents.

Genitalia black; differing from all other known nearctic species in having an exceedingly long keel-like portion at the base of the inner forceps (named on account of this unusually long keel). The basal part of the outer forceps covered over by a broad, leaf-like portion.

The horseshoe-shaped indenture of the last sternite extending slightly more than half the distance to the base of the blade.

Described from four males collected by Mr. E. C. Van Dyke at Lake Tahoe, California on September 2oth.

Type and one paratype in the Cal. Acad. Sci. One paratype in the Cananadian National Collection, Ottawa. One paratype in the U. S. N. M.

(To be Continued.)

A REVIEW OF THE GENUS MONOCHAMUS SERV. (CERAMBYCIDAE, COL,EOPTERA)

BY RALPH HOPPING,

Entomological Branch, Department of Agriculture, Ottawa.

A study of long series of the different species of this genus has made it evident that a few changes in the synonomy are necessary. The writer's interpretation of the North American species is expressed in the accompanying key. 